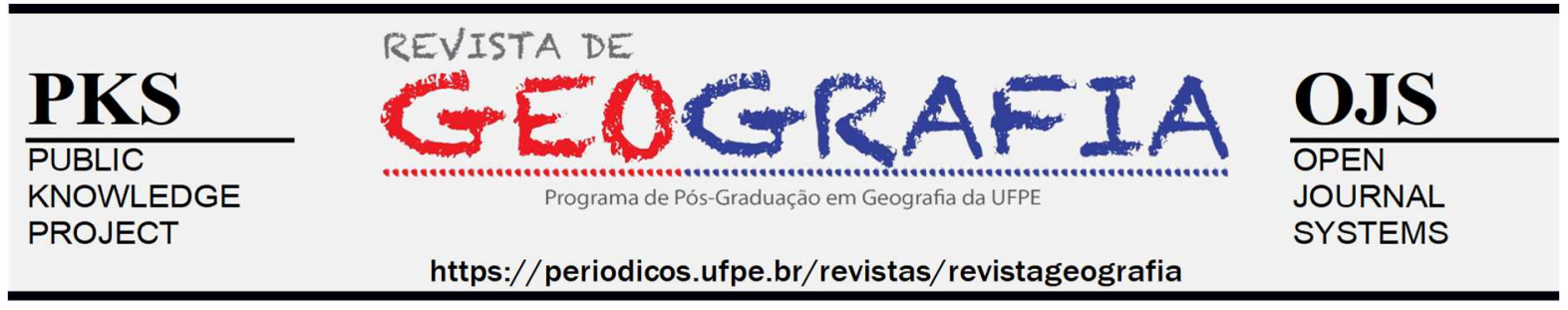

\title{
INFLUÊNCIA DO USO E OCUPAÇÃO DO SOLO NA QUALIDADE DA ÁGUA NO RIO ITAJAÍ-AÇU, SANTA CATARINA
}

\author{
Isabel Cristina Bohn Vieira ${ }^{1}$, Eduardo Augusto Werneck Ribeiro ${ }^{2}$
}

\begin{abstract}
${ }^{1}$ Mestra em Ciências Ambientais. Instituto Federal Catarinense (IFC), Programa de Pós-graduação Tecnologia e Ambiente (PPGTA). E-mail: isabelbohnvieira@gmail.com, http://orcid.org/0000-0003-2338-9322.

2 Doutor em Geografia, Docente do Instituto Federal Catarinense e dos Programas de Pós-Graduação em Tecnologia e Ambiente (PPGTA) e Educação Profissional e Tecnologia (ProfEPT). E-mail: eduardo.werneck@ifc.edu.br, http://orcid.org/0000-0003-3313-6783.
\end{abstract}

Artigo recebido em 13/11/2020 e aceito em 07/07/2021

\begin{abstract}
RESUMO
Os usos inapropriados dos recursos hídricos pelas ações antropogênicas, colocam em risco o equilíbrio entre os fatores naturais e antrópicos. Nesse ensejo, o presente trabalho tem como objetivo entender quais são as relações entre o uso e ocupação do solo e qualidade da água, ao longo do rio Itajaí-Açu, o maior curso d'água da bacia hidrográfica do rio Itajaí, localizado no Estado de Santa Catarina. Para análise da qualidade da água, foram coletadas 80 amostras, nos indicativos químicos e biológicos, entre a primavera/2019 e inverno/2020. A caracterização do uso e ocupação do solo foi executada com imagens obtidas no site da Copernicus Open Access Hub, satélite Sentinel 2, sensor de 10m e processadas no software Qgis, versão 2.18, classificação supervisionada. Objetivando consolidar a pesquisa, efetuou-se a correlação estatística no Software Estatístico R, versão 3.6.3. Os resultados obtidos apontaram para a contaminação química e biológica significativa ao longo de todo o curso hídrico, bem como a contaminação biológica à montante da confluência do rio. A falta de saneamento básico e a ausência ou precariedade de um plano de gestão para o uso adequado do solo nos municípios às margens do rio Itajaí-Açu ficou evidenciado na presente pesquisa.
\end{abstract}

Palavras-chave: bacia hidrográfica; correlação estatística; qualidade da água; uso e ocupação do solo.

\section{INFLUENCE OF SOIL USE AND OCCUPATION ON WATER QUALITY IN ITAJAÍ-AÇU RIVER, SANTA CATARINA}

\begin{abstract}
The inappropriate uses of water resources by anthropogenic actions, jeopardize the balance between natural and man-made factors. In this opportunity, the present work aims to understand what are the relationships between land use and occupation and water quality, along the Itajaí-Açu River, the largest watercourse in the Itajai River basin, located in the State of Santa Catarina. For water quality analysis, 80 samples were collected, in chemical and biological indications, between spring / 2019 and winter / 2020. The characterization of land use and occupation was performed using images obtained from the
\end{abstract}


Copernicus Open Access Hub website, Sentinel 2 satellite, $10 \mathrm{~m}$ sensor and processed using Qgis software, version 2.18, supervised classification. In order to consolidate the research, a statistical correlation was made in the Statistical Software R, version 3.6.3. The results obtained pointed to significant chemical and biological contamination throughout the entire water course, as well as biological contamination upstream of the confluence of the river. The lack of basic sanitation and the absence or precariousness of a management plan for the adequate use of the soil in the municipalities on the banks of the Itajaí-Açu river was evidenced in the present research.

Keywords: hydrographic basin; statistical correlation; water quality; land use and occupation.

\title{
INFLUENCIA DEL USO Y OCUPACIÓN DEL SUELO EN LA CALIDAD DEL AGUA EN UNA CUENCA HIDROGRÁFICA DEL ESTADO DE SANTA CATARINA
}

\begin{abstract}
O
Los usos inadecuados de los recursos hídricos por acciones antropogénicas, comprometen el equilibrio entre factores naturales y antropogénicos. En esta oportunidad, el presente trabajo tiene como objetivo comprender cuáles son las relaciones entre uso y ocupación del suelo y calidad del agua, a lo largo del río Itajaí-Açu, el curso de agua más grande de la cuenca del río Itajaí, ubicado en el Estado. de Santa Catarina. Para el análisis de la calidad del agua se recolectaron 80 muestras, en indicaciones químicas y biológicas, entre primavera / 2019 e invierno / 2020. La caracterización del uso y ocupación del suelo se realizó mediante imágenes obtenidas del sitio web Copernicus Open Access Hub, satélite Sentinel 2, sensor de $10 \mathrm{~m}$ y procesadas mediante el software Qgis, versión 2.18, clasificación supervisada. Para consolidar la investigación se realizó una correlación estadística en el Software Estadístico R, versión 3.6.3. Los resultados obtenidos apuntaban a una importante contaminación química y biológica en todo el curso de agua, así como a una contaminación biológica aguas arriba de la confluencia del río. La falta de saneamiento básico y la ausencia o precariedad de un plan de manejo para el uso adecuado del suelo en los municipios de la ribera del río Itajaí-Açu se evidencia en la presente investigación.
\end{abstract}

Palabras clave: bacia hidrográfica; correlação estatística; qualidade da água; uso e ocupação do solo.

\section{INTRODUÇÃO}

Os recursos hídricos são indispensáveis para o crescimento da economia de um território, bem como para o provimento da manutenção das atividades básicas à sobrevivência humana. No entanto, as atividades humanas realizadas no seu entorno têm provocado significativa queda na qualidade da água e na biodiversidade, decorrente das alterações do ambiente físico, químico e biológico (OKUMURA et al., 2020)

A expansão das áreas agrícolas, o aumento dos aglomerados urbanos, a exploração dos recursos naturais, são exemplos de ações antrópicas que provocam rápidas alterações na cobertura do solo e, aliadas ao desenvolvimento contínuo e mal planejado, geram impactos ambientais e socioeconômicos (SANTOS et al., 2019). 
Diante desse panorama, diversos estudos têm apresentado uma relação direta entre o uso do solo, manutenção de cobertura vegetal e as alterações na qualidade da água dos cursos hídricos. Conforme trabalho realizado por Freire e Castro (2014) em bacia hidrográfica no Estado do Espírito Santo, houve correlação positiva forte de 0,87 entre o Índice de Degradação da Água (associada a pouco oxigênio dissolvido e alta concentração de nitratos) e o Índice de Atividade Humana do Solo (associado a exposição do solo e a pastagem). Pereira (2016) em estudo na Bacia Hidrográfica do Alto Tietê, obteve alta correlação com as concentrações dos nutrientes na água, oriundos da ocupação humana ao entorno da bacia e evidenciou a importância do estudo do uso e ocupação do solo na qualidade de corpos hídricos. Já, Cornelli et al. (2016), acurou que a mata nativa presente em sub-bacias no município de Caxias do Sul, RS, é capaz de atenuar a carga de poluentes lançadas no curso hídrico melhorando qualidade da água.

Bacias hidrográficas são áreas drenadas por um rio ou sistema fluvial que deságua em um ponto comum, onde as águas das chuvas escoam superficialmente ou se infiltram no solo, formando nascentes, cursos de água e recarregando lençóis freáticos (FURLAN; FILIPINI; REIS, 2016). Contudo, drasticamente, desde os primórdios, as bacias hidrográficas servem como recipientes dos poluentes da terra e da atmosfera, haja vista que, o ser humano estabeleceu-se às margens dos rios, onde desenvolveu seus aglomerados urbanos e industriais. Por serem consideradas como unidade de planejamento ou unidade espacial, no qual um conjunto de terras topograficamente drenadas por um curso d'água e seus afluentes são integrados a uma área de terra, emerge a preocupação com o seu manejo e manutenção salutar dos recursos (MARTINS; LOPES; SIMEDO, 2015).

Em 1997, buscando prover a manutenção desses cursos hídricos, a Lei n 9.433 instituiu a Política Nacional de Recursos Hídricos (PNRH) no Brasil, conhecida como a "Lei das Águas”. Esta, por sua vez, além da contribuir para a Gestão dos Recursos Hídricos no país, incorporou a participação social na gestão destes recursos, implementando a participação de órgãos e agências, Conselhos Nacional e Estadual de Recursos Hídricos e por Comitês de Bacias Hidrográficas (BRASIL, 1997).

Esses órgãos intermedeiam as relações entre Federação, Estado e Município e abarcam em sua composição, representantes do poder público, usuários de água e sociedade civil. Seus atores, articulam o diálogo e formulam os Planos Nacionais de Recursos Hídricos e Planos de 
Bacias, onde são dadas as diretrizes para o planejamento das bacias hidrográficas e gestão da água, bem como seu monitoramento.

O monitoramento é um dos instrumentos de gestão estabelecidos na Política Nacional de Recursos Hídricos, com vistas ao enquadramento dos corpos d'água em classes, segundo os usos preponderantes da água. Para este enquadramento, com base nas orientações legais que tratam da qualidade das águas no Brasil, a resolução no 357 do Conselho Nacional do Meio Ambiente (CONAMA), dispõe sobre a classificação e diretrizes ambientais para os corpos de água superficiais, estabelecendo parâmetros e/ou limites individuais a cada indicativo a ser analisado (BRASIL, 2005). Os parâmetros químicos, físicos e biológicos mensurados em um corpo hídrico podem indicar o grau de contaminação das águas e oferece a base no gerenciamento do referido recurso, auxiliando na tomada de decisão, foco na manutenção, remedição e proteção do mesmo.

Nesse contexto, o desenvolvimento de políticas e diretrizes voltadas ao planejamento territorial com vistas a qualidade das águas nas bacias hidrográficas e sua ocupação, proporcionando o desenvolvimento sustentável, a identificação do uso e ocupação do solo se faz necessária (ASCIUTTI; STANGANINI; MELANDA, 2019). O uso de imagens de satélite e ferramentas de geoprocessamento permitem a geração de dados da superfície, reconhecimento a dinâmica de ocupação e utilização da terra, bem como o acompanhamento da evolução e da transformação do território brasileiro no controle dos impactos das atividades humanas sobre o meio ambiente.

Conforme Silva (2015), a interpretação de imagens de satélite associado aos parâmetros de qualidade da água em um rio, permite diagnosticar a condição atual do rio, identificar os problemas mais relevantes de qualidade da água e correlacionar com o comprometimento do uso e ocupação do solo. Esse monitoramento é capaz de contribuir para consubstanciar a importância da preservação dos recursos naturais, e consequente qualidade de vida e de saúde da população que vive a suas margens ou em área adstrita.

Destarte, o objetivo da presente pesquisa consistiu em quantificar as classes, a partir de imagens de satélite, o uso e ocupação do solo às margens do rio Itajaí- Açu, o maior curso d'água da bacia do rio Itajaí, localizado no Estado de Santa Catarina, e as correlacionar com a qualidade da água nos indicadores químicos e biológicos deste rio, durante quatro estações do 
ano, em diferentes pontos do território, a fim de diagnosticar a influência antrópica nesse ecossistema nos diferentes períodos.

\section{METODOLOGIA}

Nesta seção foram abordadas as etapas da presente pesquisa: descrição da área de estudo, monitoramento químico e biológico de água e caracterização do uso e ocupação do solo com a descrição da metodologia estatística.

Visando elucidar a organização das etapas de pesquisa que se encontram descritas na sequência, segue abaixo na figura 1 , o organograma da propositura.

Figura 1. Organograma da Pesquisa

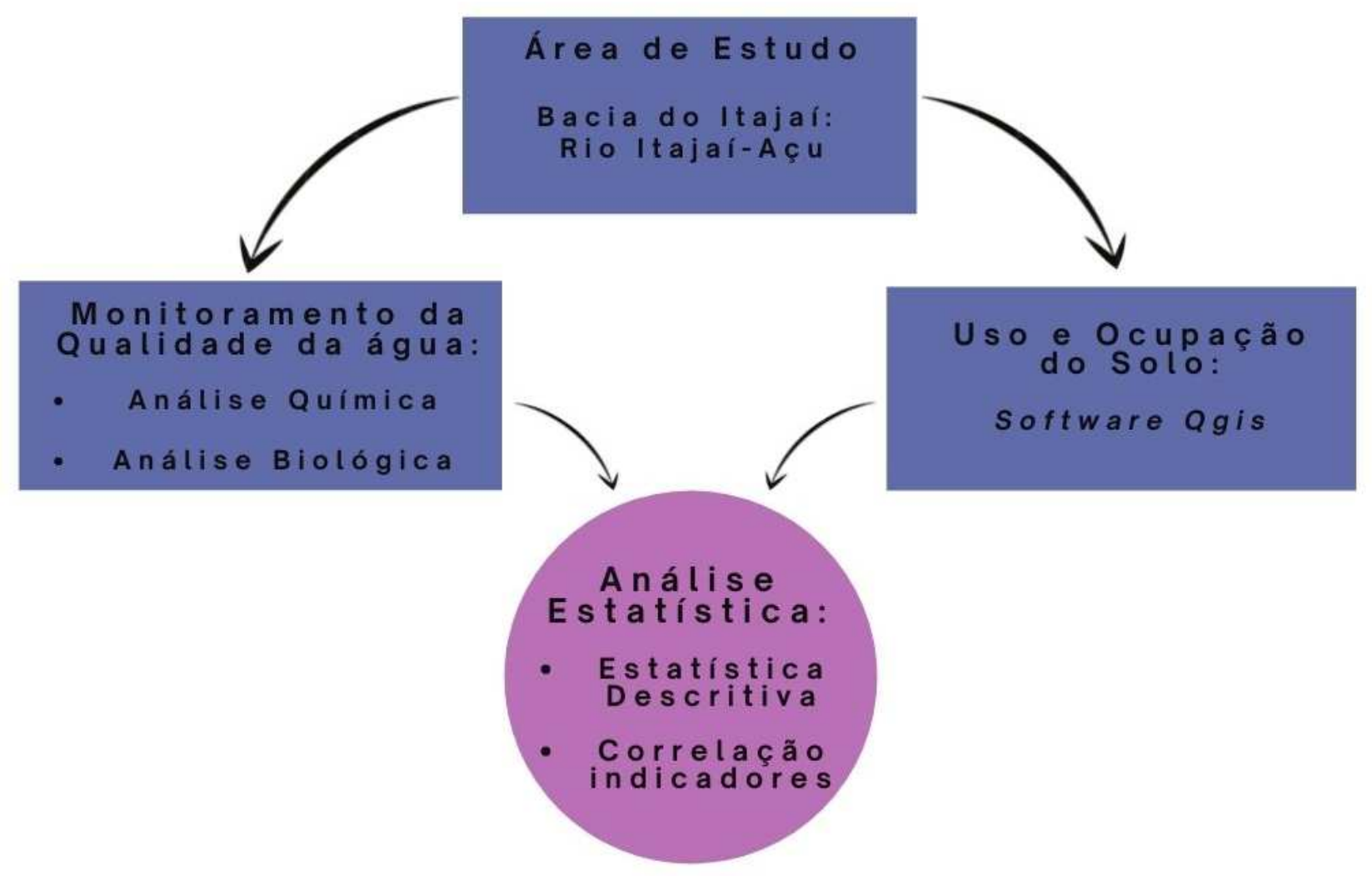

Fonte: organizado pelos autores, 2020.

\section{Área de estudo}

A bacia hidrográfica do rio Itajaí tem uma área total de $15,000 \mathrm{~km}^{2}$, que corresponde a $16,15 \%$ do território catarinense, com aproximadamente 1.466 .885 habitantes, segundo dados 
IBGE. Esta parcela populacional da bacia, 18,6\% dos habitantes do estado, produz diariamente uma quantidade aproximada de 234.701,67 $\mathrm{m}^{3}$ de efluentes domésticos (PLANO DE RECURSOS HÍDRICOS DA BACIA DO ITAJAÍ, 2010; IBGE, 2020).

Abrangendo 52 municípios em seu território, a bacia do Itajaí se divide naturalmente em sete sub-bacias hidrográficas principais. Seu relevo indica uma grande diversidade e complexidade geoecológica, suscetível à dinâmica dos processos erosivos ação antropogênica e consequente fragilidade ambiental. O clima da bacia do Itajaí é caracterizado por uma média anual entre 19 e $21^{\circ} \mathrm{C}$, por um verão quente e úmido e um inverno ameno. A média de chuvas é de 120 a 180 dias no ano (PLANO DE RECURSOS HÍDRICOS DA BACIA DO ITAJAÍ, 2010).

O maior curso d'água da bacia do Itajaí é o rio Itajaí-Açu, formado pela junção dos rios Itajaí do Oeste e Itajaí do Sul, no município de Rio do Sul. Com 12 municípios em suas margens, o rio Itajaí-Açu movimenta economicamente a agricultura e pecuária no estado de Santa Catarina, ao longo de seus 188,0 Km de comprimento e 2.780,0 $\mathrm{Km}^{2}$ de área. (PLANO DE RECURSOS HIIIDRICOS DA BACIA DO ITAJAÍ).

A localização do rio Itajaí-Açu está representada pela figura 2.

Figura 2. Localização do rio Itajaí-Açu
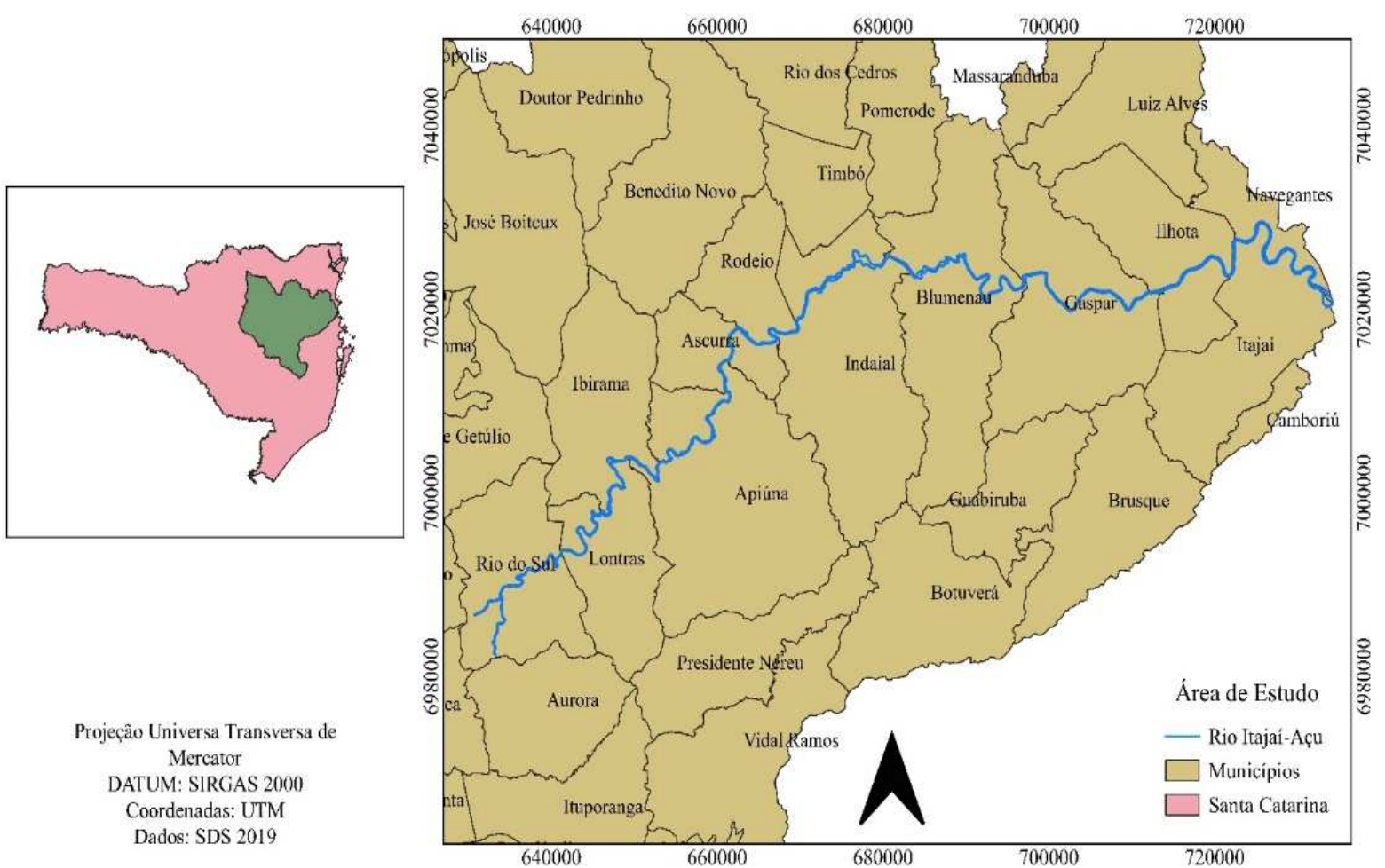

Fonte: organizado pelos autores, 2020. 
Foram alocados cinco pontos de coleta de água ao longo do rio Itajaí-Açu para o estudo do monitoramento da qualidade da água, como mostra a figura 3. O primeiro ponto, na formação do rio no município de Rio do Sul e o último na foz, no município de Navegantes. A escolha dos demais pontos de coleta sucederam-se em ordem a partir do primeiro em área de vegetação, município de Apiúna, área urbana, município de Blumenau e área de campo aberto, município de Ilhota.

Figura 3. Indicação dos pontos amostrais ao longo do rio Itajaí-Açu

\section{Pontos de coleta no rio Itajaí-açu - Santa Catarina}
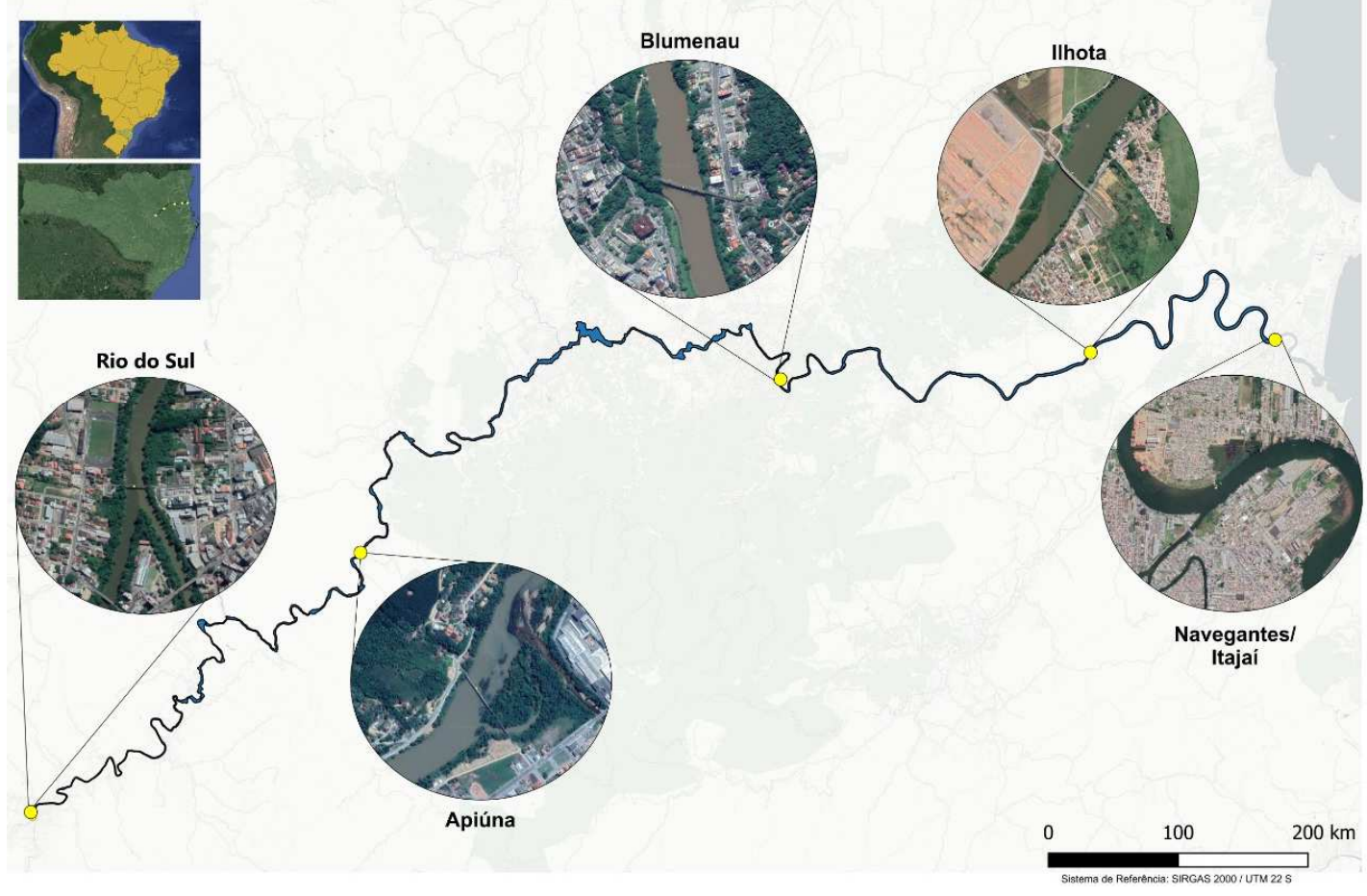

Fonte: organizado pelos autores, 2020.

O plano amostral por estação sazonal e número amostral foi embasado na literatura por diferentes autores, em diferentes locais do Brasil. Segundo De Mendonça, et al. (2016) em análise de córrego no Estado de Minas Gerais, houve variância média entre as estações de seca e chuva ou entre os pontos monitorados com duas coletas anuais em dois pontos, resultando em suficiência para descrever o comportamento da qualidade da água na bacia. Conforme estudo de Andrietti et al. (2016), maiores concentrações de poluentes em função da sazonalidade, para os parâmetros coliformes totais e nitrito são reportados nos períodos de chuva em rio Caibi, no Estado do Mato Grosso. Lima, Bethonico e Vital (2015), em estudo de bacia hidrográfica no Estado de Roraima em dados amostrais nos meses dezembro de 2014 e fevereiro de 2015 
(período da seca), maio e julho de 2015 (período da cheia); totalizando 26 amostras em quatro datas distintas para análises microbiológicas e físico-químicas em cada período confirmaram que qualidade da água relaciona-se diretamente com a forma de uso e ocupação das áreas em uma bacia hidrográfica.

\section{Monitoramento químico e biológico da água}

Os parâmetros utilizados como variáveis para fazer o monitoramento da qualidade da água do rio Itajaí-Açu, foram selecionados conforme a Resolução n 357/2005 do Conselho Nacional do Meio Ambiente (CONAMA). Como indicadores químicos: nitrito e nitrato; e biológicos: coliformes termotolerantes e coliformes totais, nas estações primavera, verão (2019), outono e inverno (2020).

A predileção de análise dos indicadores nitrito e nitrato em águas superficiais, atua como desígnio respectivamente, na ocorrência de processos biológicos ativos influenciados por poluição orgânica e no escoamento de terras agrícolas para rios e riachos devido ao uso de fertilizantes na agricultura (FONSECA, 2017). Já, o grupo coliforme, por habitar o intestino de mamíferos, inclusive do ser humano, a sua presença no ambiente aquático é indicador de contaminação fecal, sendo considerado o bioindicador básico no parâmetro das legislações relativas à água para consumo humano, bem como, no monitoramento da qualidade de águas destinadas a potabilidade e balneabilidade (NUNES et al., 2019).

Conforme o plano amostral apontado na figura 3, nos indicadores supracitados, foram realizadas quatro coletas contemplando as quatro estações sazonais, totalizando 80 amostras ao longo do rio Itajaí-Açu. As amostras foram analisadas pela Central de Laboratórios de Ensaios Analíticos, UNIVALI - CLEAn, no município de Itajaí - SC, que seguiu as referências normativas Standard Methods for the Examination of Water and Wastewater (GREENBERG; CLESCERI; EATON, 1992).

\section{Caracterização do uso e ocupação do solo}

A execução do trabalho aconteceu a partir do descarregamento gratuito dos arquivos com imagens das margens rio Itajaí-Açu no site da Copernicus Open Access Hub, programa da Agência Espacial Europeia (ESA). Foram obtidas imagens do satélite Sentinel 2, sensor de 10m (Bottom of Atmosphere), com cenas das áreas de órbita T22JGR, T22JFQ e T22JFR datadas de 
agosto de 2019. Com o software Qgis - versão 2.18, efetuou-se a composição de bandas falsa cor, B08, B03, B04 e posterior mosaico com as bandas B04, B03, B02 delimitando assim, a área paralela às margens um buffer de 300 metros (QGIS, 2019). A classificação foi sucedida por meio do complemento Dzetsaka Plugin, automático, em cinco classes: urbanização, pastagem e campo aberto, agricultura, lagos e massas d'água e vegetação, conforme demonstra o quadro 1.

Com o plugin dzetsaka, método de classificação supervisionada desenvolvido por Nicolas Karasiak, o qual utiliza um classificador GMM (Gaussian Mixture Model), ou Modelo de Mistura Gaussiana, foi realizado o processo automático de classificação do raster em falsa cor com as amostras criadas (KARASIAK, 2019). Com a imagem raster classificada, validouse as feições identificadas pelo algoritmo com a imagem de cor verdadeira.

Quadro 1. Classes utilizadas para treinamento do algoritmo na classificação supervisionada

\begin{tabular}{lcc}
\hline Código da Feição & Nome da Classe & Exemplo da Interpretação \\
\hline 1 & Urbanização & áreas residências, infraestrutura, rodovias, edificações \\
& isoladas e áreas industriais. \\
2 & $\begin{array}{c}\text { Pastagem e Campo } \\
\text { Aberto }\end{array}$ & pastagem de animais, campos abertos sem animais, campos \\
3 & Agricultura & rizicultura, bananicultura e outros plantios identificados. \\
4 & Lagos e Massa & açudes artificiais, banhados e entrada de rios. \\
& d'água & remanescentes vegetais de Floresta Ombrófila Densa (FOD), \\
5 & Vegetação & capoeirões, arbustos e reflorestamentos. \\
\hline
\end{tabular}

Em seguida a imagem classificada foi transformada para o formato shapefile, gerando polígonos para as classes identificadas, onde foi quantificada a área de cada classe por trecho ao longo do rio (figura 4). 
Figura 4. Classes de uso e ocupação do solo no rio Itajaí-Açu

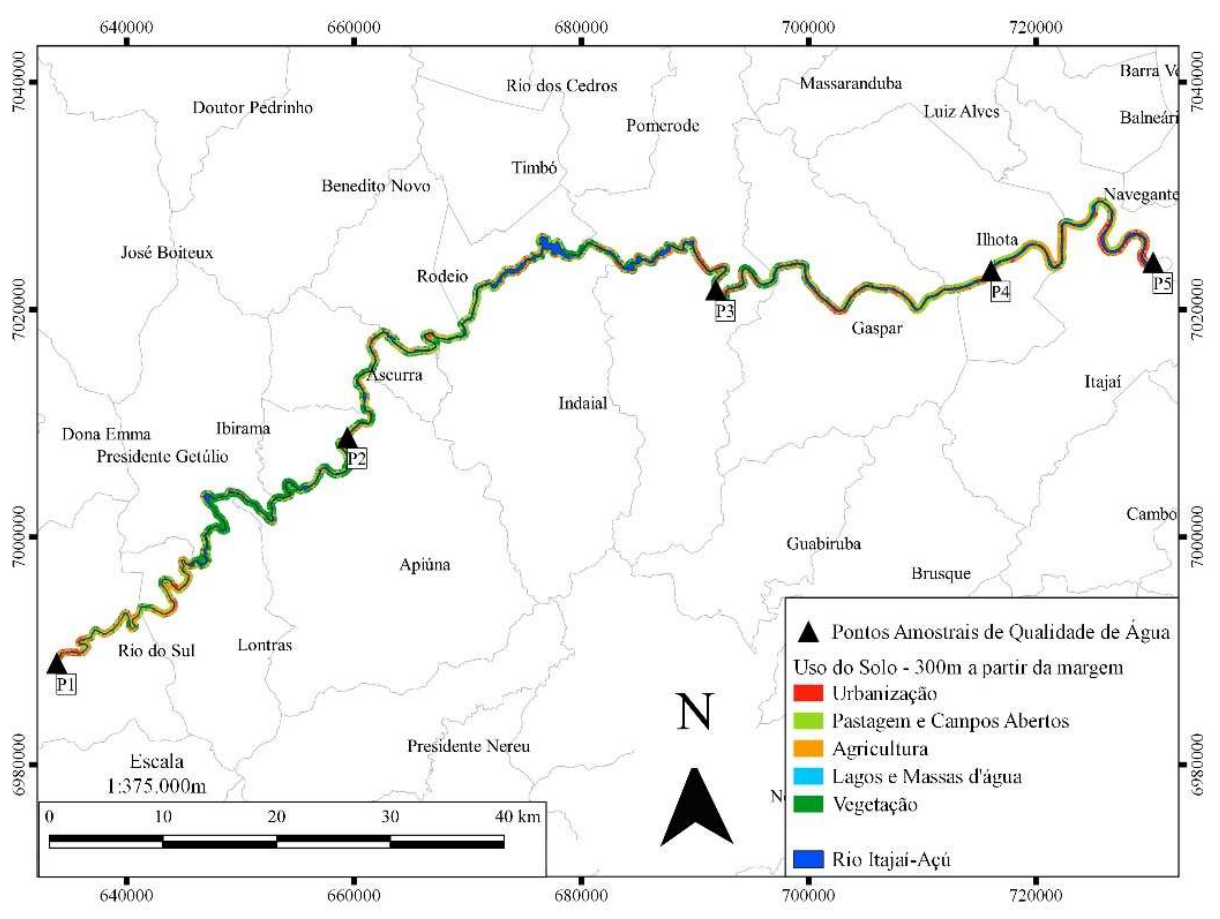

Fonte: organizado pelos autores, 2020.

Conforme Asciutti, Stanganini e Melandato (2019) o software Qgis é uma ferramenta viável no levantamento de uso e ocupação do solo utilizando imagens aéreas em estudo de Bacia Hidrográfica. Ykeizumi, Vieira e Kroth (2019), afirmam que o sistema de geoprocessamento utilizando o plugin dzetsaka para a pesquisa de imagens e geração de mapas de uso da terra, favorece à caracterização e o dimensionamento das práticas do uso do solo.

A caracterização do uso e ocupação do solo foi distribuída em quatro trechos amostrais, sendo considerado o trecho 1 , do ponto de coleta de água na formação do rio (P1) até o ponto 2 (P2); trecho 2 do ponto de coleta de água 2 (P2) até o ponto 3( P3); sucessivamente, trechos 3 e 4 (foz).

Para consolidar o objetivo proposto nesta pesquisa, correlação entre o uso e ocupação do solo e a qualidade da água, utilizou-se do apoio do Software Estatístico R (R Development Core Team, 2020), versão 3.6.3, para estatística descritiva, teste de normalidade dos dados (Shapiro-Wilk), seguido da análise de significância entre as variáveis (teste Kuskall Wallis), e posterior correlação entre os indicativos com aplicação do teste de Spearman. 


\section{RESULTADOS E DISCUSSÃO}

Foram classificados 109,16 km² de áreas nos 300 metros do buffer às margens do rio Itajaí-Açu, desde a sua confluência (P1) até a estação amostral 5 (P5), próximo da foz do rio.

Conforme dados representados abaixo na tabela 1 , a classe de uso do solo mais representativa foi a vegetação com $34,42 \%\left(37,57 \mathrm{Km}^{2}\right)$ de cobertura, seguida das pastagens e campos abertos com $27,83 \%\left(30,38 \mathrm{Km}^{2}\right)$, agricultura $18,18 \%\left(19,85 \mathrm{Km}^{2}\right)$ e urbanização com $16,59 \%\left(18,11 \mathrm{Km}^{2}\right)$.

Tabela 1. Classificação do uso e ocupação do solo e suas respectivas áreas e percentuais de cobertura

\begin{tabular}{|c|c|c|}
\hline Classe & Área $\left[\mathrm{km}^{2}\right]$ & \% de cobertura \\
\hline Urbanização & 18,11 & 16,59 \\
\hline Pastagem e Campo Aberto & 30,38 & 27,83 \\
\hline Agricultura & 19,85 & 18,18 \\
\hline Lagos e Massa d'água & 3,25 & 2,98 \\
\hline Vegetação & 37,57 & 34,42 \\
\hline Total & 109,16 & 100 \\
\hline
\end{tabular}

Fonte: organizado pelos autores, 2020.

De acordo com a tabela 1 , podemos contabilizar que a área de estudo apresenta 62,6\% de seu território sob a influência antrópica o que caracteriza um ambiente severamente alterado. Resultados semelhantes foram obtidos por Santos et al. (2019), em monitoramento de bacia hidrográfica no Estado de Goiás e por Almeida, Bayer e Ferreira Junior (2016) em bacia hidrográfica no Estado de Tocantins. Corroborando com os autores, este presente estudo no que diz respeito às atividades de uso e ocupação do solo, ratifica-se as fragilidades ambientais, as quais poderão potencializar processos naturais, com intensificação de perda de solo por erosão e consequente assoreamento e diminuição da qualidade da água.

A classificação de uso e ocupação do solo por trecho amostral, está representado espacialmente nos mapas (figura 5), conforme classificador GMM (Gaussian Mixture Model), ou Modelo de Mistura Gaussiana, atestando a representatividade das classes. 
Figura 5. Classes de uso e ocupação do solo no rio Itajaí-Açu por trechos
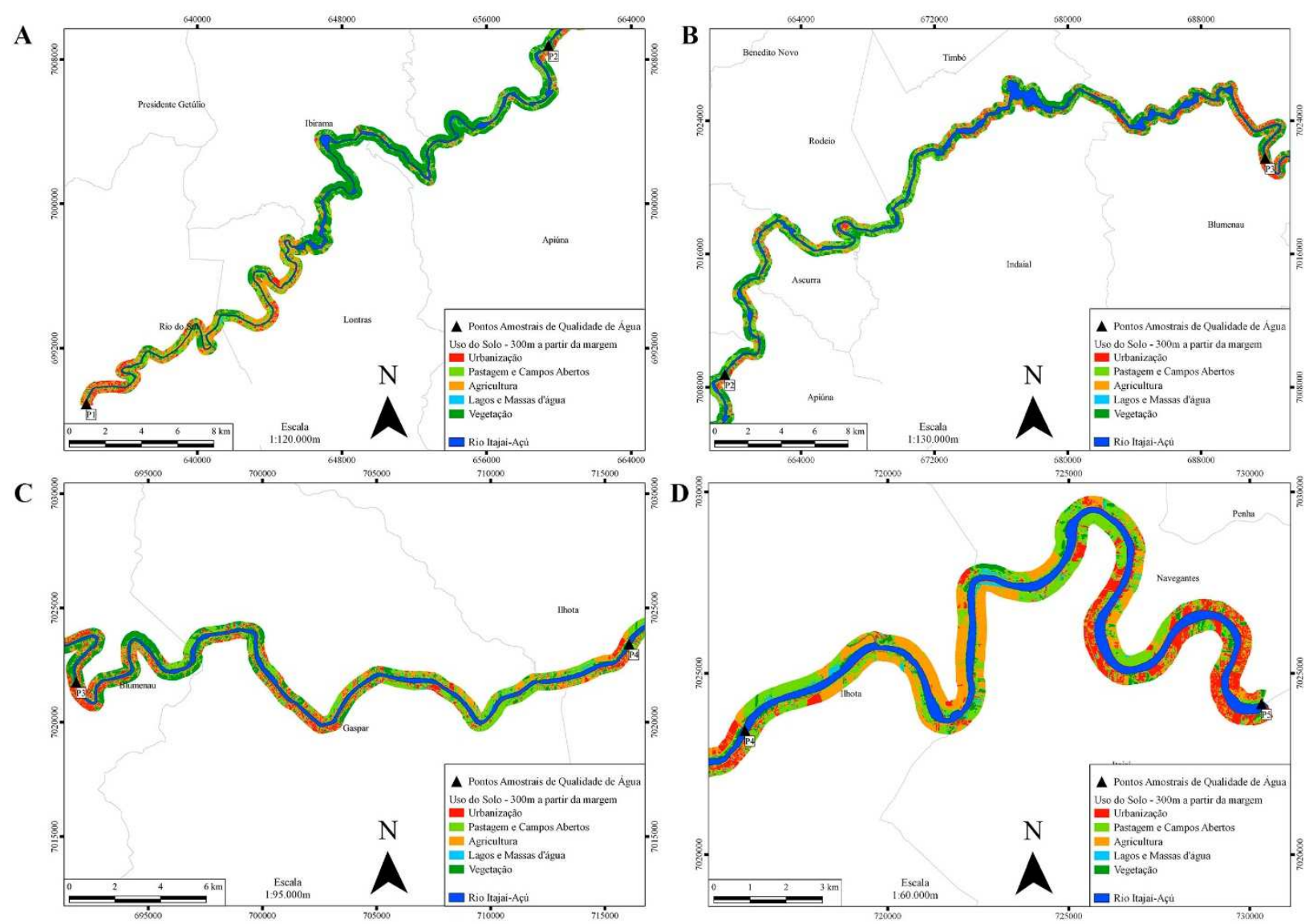

Fonte: organizado pelos autores, 2020.

O trecho 1, compreende o território entre a formação do rio Itajaí-Açu até o município de Apiúna (figura 5a); trecho 2 de Apiúna a Blumenau (figura 5b); trecho 3 de Blumenau a Ilhota (figura 5c) e por fim, trecho 4 de Ilhota ao município de Navegantes, foz do rio (figura 5d).

Os valores de cobertura territorial por área nos quatro trechos que compõe o rio ItajaíAçu, conforme o plano amostral, estão representados na tabela 2. 
Tabela 2. Classificação do uso e ocupação do solo por trechos

\begin{tabular}{ccccc}
\hline \multirow{2}{*}{ Classe } & \multicolumn{2}{c}{ Área $\left[\mathrm{km}^{2}\right]$} & \\
& Trecho 1 & Trecho 2 & Trecho 3 & Trecho 4 \\
\hline Urbanização & 4,25 & 5,69 & 4,36 & 3,81 \\
Pastagem e Campo Aberto & 7,38 & 10,19 & 6,68 & 6,13 \\
Agricultura & 5,69 & 5,02 & 3,61 & 5,53 \\
Lagos e Massa d'água & 0,86 & 1,12 & 0,74 & 0,53 \\
Vegetação & 16,55 & 14,73 & 5,03 & 1,26 \\
\hline Total & $\mathbf{3 4 , 7 3}$ & $\mathbf{3 6 , 7 5}$ & $\mathbf{2 0 , 4 2}$ & $\mathbf{1 7 , 2 6}$ \\
\hline
\end{tabular}

Fonte: organizado pelos autores, 2020.

Em análise de uso e ocupação do solo por trecho (tabela 2) as margens do rio ItajaíAçu, verificou-se que no trecho 2, área compreendida entre os municípios de Apiúna a Blumenau, a classes urbanização $\left(5,69 \mathrm{Km}^{2}\right)$; pastagem e campo aberto $\left(10,19 \mathrm{Km}^{2}\right)$; e lagos e massa d'água $\left(1,12 \mathrm{Km}^{2}\right)$, foram mais representativas em detrimentos aos outros trechos. Dados esses, justificados por Blumenau, conforme o último censo do IBGE, compor o maior índice populacional da bacia do Itajaí (309.011 habitantes) e o terceiro lugar no estado de Santa Catarina, evidenciando assim, a ação antrópica nesse território (IBGE, 2020).

No trecho 1, compreendido entre a formação do rio Itajaí-Açu, no município de Rio do Sul, e Apiúna, foi destacado na representatividade na classe agricultura $\left(5,69 \mathrm{Km}^{2}\right)$ e também na classe vegetação $\left(16,55 \mathrm{Km}^{2}\right)$. Dados confrontados, conforme valores territoriais do IBGE e censo agropecuário, com os demais municípios de localização amostral, os municípios de Rio do Sul e Apiúna apresentam respectivamente, $32,43 \%$ e $22,56 \%$ da totalidade se seu território composto por matas e florestas, enquanto Blumenau, Ilhota e Navegantes apresentam respectivamente, $12,53 \%, 21,96 \%$ e 4,55\% de seu território preservado. Isso demonstra que a área de preservação do território condiz com a área preservada de vegetação às margens do rio Itajaí-Açu. Entretanto, para a classe agricultura, considerando lavouras permanentes e temporárias, conforme dados do IBGE (2020), o trecho 1 soma 10,2\% do seu território com cultivos, o trecho 2 soma 4\%, o trecho 3,11,99\% e o trecho 4 soma 16,99\% de área territorial agricultável, valores que quando comparados com o uso do solo às margens do rio demostrados na tabela 2, apresentam discrepância entre os dados. Essa diferença revela que as áreas de cultivo se encontram mais distantes das margens do rio se comparado a totalidade do território. 
Executando a análise descritiva das análises nos cinco pontos de coleta de água dos parâmetros químicos e biológicos, abarcando as quatro estações do ano, com o Software Estatístico R (R Development Core Team, 2020), obtivemos os resultados demonstrados na figura 6. A linha representada em vermelho nas figuras, corresponde aos padrões de potabilidade da água estabelecidos pela resolução n³57/2005 do CONAMA.

Figura 6. Análise descritiva dos parâmetros químicos e biológicos da água no rio Itajaí-Açu
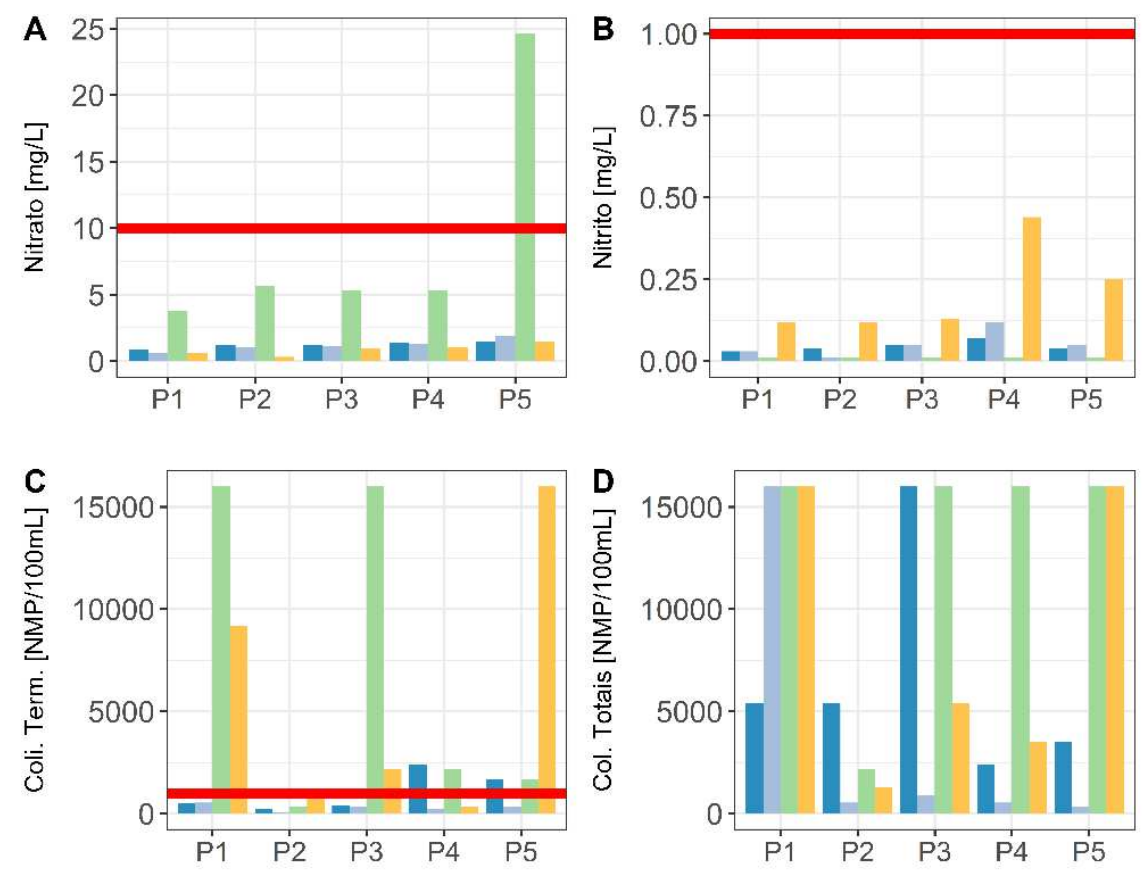

Estação do Ano Inverno Outono Primavera Verão

Fonte: organizado pelos autores, 2020.

Conforme os gráficos para os indicadores químicos, os valores de nitrato variaram de $0,31 \mathrm{mg} / \mathrm{L}$ no ponto 2 - verão, a 24,61 $\mathrm{mg} / \mathrm{L}$ no ponto 5 , primavera $(\bar{X}=3,057 \pm 5,34$; média e desvio padrão respectivamente), figura 6a. A desconformidade dos padrões de potabilidade da água em relação a resolução $\mathrm{n}^{\circ}$ 357/200 do CONAMA observada na estação primavera em P5, região de foz do rio Itajaí-Açu, pode ser atribuída as áreas agricultáveis no trecho 4, sendo o segundo mais representativo para a classificação de uso e ocupação do solo $\left(5,53 \mathrm{Km}^{2}\right)$ às margens do rio e o primeiro em relação ao território, segundo censo agropecuário do IBGE. Na estação supracitada, o valor da precipitação acumulada foi o maior $(21,4 \mathrm{~mm})$, se comparado as demais estações, lixiviando assim, o indicativo para o curso hídrico. Conforme Fonseca, 
(2017, p.15) “o aumento nos níveis dos íons nitrato na água de consumo, especialmente em áreas rurais; onde a principal fonte deste nitrato é o escoamento que ocorre de terras agrícolas para rios e riachos é devido ao uso de fertilizantes".

Os resultados para o indicativo nitrito oscilaram de $0,01 \mathrm{mg} / \mathrm{L}$ nos pontos $\mathrm{P} 1$ ao $\mathrm{P} 5 \mathrm{na}$ primavera, a $0,44 \mathrm{mg} / \mathrm{L}$ no ponto $\mathrm{P} 4$ verão $(\bar{X}=0,08 \pm 0,10)$, figura $6 \mathbf{b}$. Apesar das variações apresentadas o indicativo em alguns pontos de coleta, ainda os valores encontram-se dentro dos padrões de potabilidade de consumo da água estabelecidos em 1,0 mg/L, segundo o CONAMA. Os resultados na variação são corroborados com a presença dos coliformes totais nos mesmos pontos amostrais, haja vista que, segundo Bastos, Bezerra e Bevilacqua (2007) a presença do íon nitrito indica a ocorrência de processos biológicos ativos influenciados por poluição orgânica.

Considerando os indicativos biológicos, os coliformes termotolerantes alternaram de $49 \mathrm{NMP} / 100 \mathrm{ml}$ no ponto $\mathrm{P} 2$ no outono, a $16.000 \mathrm{NMP} / 100 \mathrm{ml}$ nos pontos $\mathrm{P} 1 \mathrm{e} \mathrm{P} 3$ na primavera e P5 no verão $(\bar{X}=3575 \pm 5.713,079)$, figura 6c. Conforme a resolução $n^{\circ} 357 / 2005$ CONAMA, são aceitáveis os valores de até 1000 NMP/100 ml, para águas destinada a consumo humano após tratamento convencional, recreação de contato primário e irrigação de hortaliças, entretanto observou-se que apenas o Ponto 2 não apresentou desconformidade com a legislação. Segundo Nunes et al. (2019) em estudo do rio Salgadinho- CE, a presença dos coliformes termotolerantes no ambiente aquático foram indicadores de contaminação fecal humana, o que resultaria na falta de saneamento básico na região. Conforme informações do Sistema Nacional de informações sobre Saneamento (SNIS), dados 2018, dos pontos amostrais analisados ao longo do rio Itajaí-Açu, apenas o município de Blumenau conta com $43 \%$ da parcela populacional atendida por rede coletora de esgoto, os demais municípios ainda fazem o uso de fossas sépticas ou não apresentam informações de destino de seus efluentes (SNIS, 2018). A potabilidade da água no Ponto 2 pode ser atribuída a vegetação representativa no trecho 1 de acordo com classificação de uso e ocupação do solo (tabela 2), tendo em vista que áreas florestadas às margens de rios atenuam a carga de poluentes lançadas pelos efluentes (VIEIRA, 2019).

Os coliformes totais, variaram de $350 \mathrm{NMP} / 100 \mathrm{ml}$ no ponto P5 outono, a 16.000 NMP/100 ml nos pontos P1, P3, P4, P5 na primavera, repetindo-se P1 e P5 no verão; P1 no outono e P3 somente no inverno $(\bar{X}=7972 \pm 6.892,43)$, figura 6d. A legislação não estabelece 
um padrão de valores para o indicativo, aponta apenas que a presença de bactérias do grupo coliformes é um indicador de microrganismos patogênicos caracterizando despejo de resíduos urbanos no curso hídrico (BRASIL, 2005). Conforme apresentado, o Ponto 2 manteve-se com os menores valores nas diferentes estações para o indicativo, já descrito acima como área de representatividade florestada. Alerta-se para o Ponto 1, o qual representa a formação do rio Itajaí-Açu, demonstrando que a água já se encontra contaminada por resíduos patogênicos oriunda da cabeceira da bacia do Itajaí.

Aplicando-se o teste de Shapiro-Wilk, para normalidade dos indicativos químicos e biológicos, verificou-se que se tratam de dados que não seguem a distribuição normal, não paramétricos, conforme os histogramas da figura 7, pela curva de Gauss, em vermelho.

Figura 7. Teste de normalidade dos indicativos químicos e biológicos do rio Itajaí-Açu

A

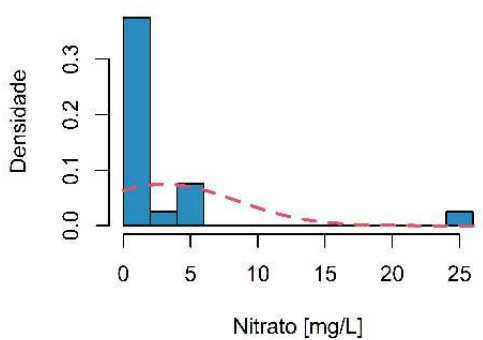

C

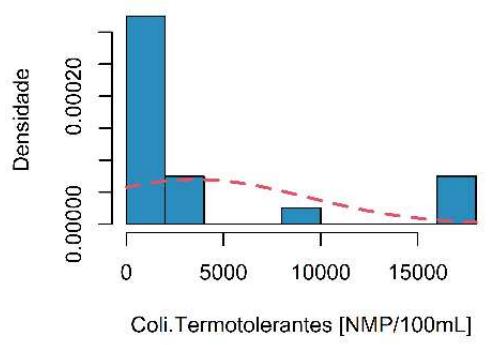

B

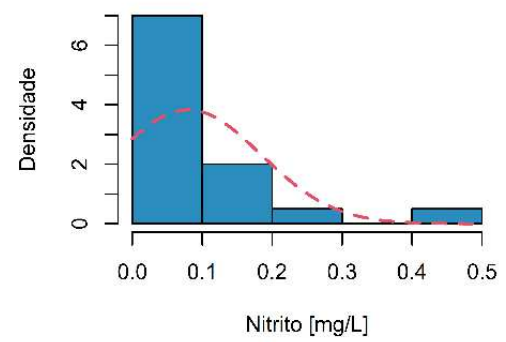

D

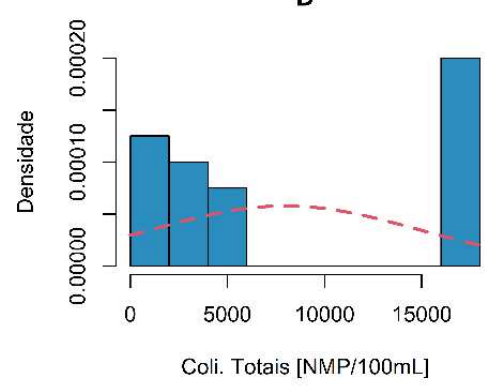

Fonte: organizado pelos autores, 2020.

Eventos naturais representados por dados contínuos assumem diferentes distribuições de frequência, entre elas uma distribuição em forma de sino, chamada curva normal ou de Gauss. A referida curva, apresenta a simetria ou normalidade dos dados, enquanto descontinuidades de dados e picos multimodais representam assimetrias, ou dados não-paramétricos (MIOT, 2017). Conforme a figura 6, as assimetrias confirmam que pelo menos uma das variáveis tende a 
produzir observações maiores que as outras, apresentando o nível de significância inferior a $0,001(\mathrm{p}<0,001)$ para os quatro indicativos, nitrato $\mathrm{p}=1,649^{-7}$ (figura 7a); nitrito $\mathrm{p}=2,076^{-5}$ (figura 7b); coliformes termotolerantes $\mathrm{p}=3,65^{-6}$ (figura 7c) e coliformes totais $\mathrm{p}=0,021^{-2}$ (figura 7d), o que demostra a probabilidade ínfima do valor aparecer novamente em relação aos demais, classificado assim como não-paramétrico. Resultados não paramétricos também foram encontrados por De Melo et al. (2020), em estudo de bacia hidrográfica no Estado do Mato Grosso; Freire (2020), em diferenças estatísticas interanuais (2013 a 2018) e sazonais da qualidade da água em trechos monitorados de 11 bacias hidrográficas do semiárido brasileiro, no estado do Ceará.

A fim de verificar se existe diferença estatística significativa entre os resultados das análises dos indicadores químicos e biológicos e os diferentes pontos amostrais, aplicou-se o teste de Kuskall Wallis, para frequência, que corrobora com os dados não paramétricos (figura 8).

Figura 8. Teste de frequências espaço-sazonais nos indicativos químicos e biológicos
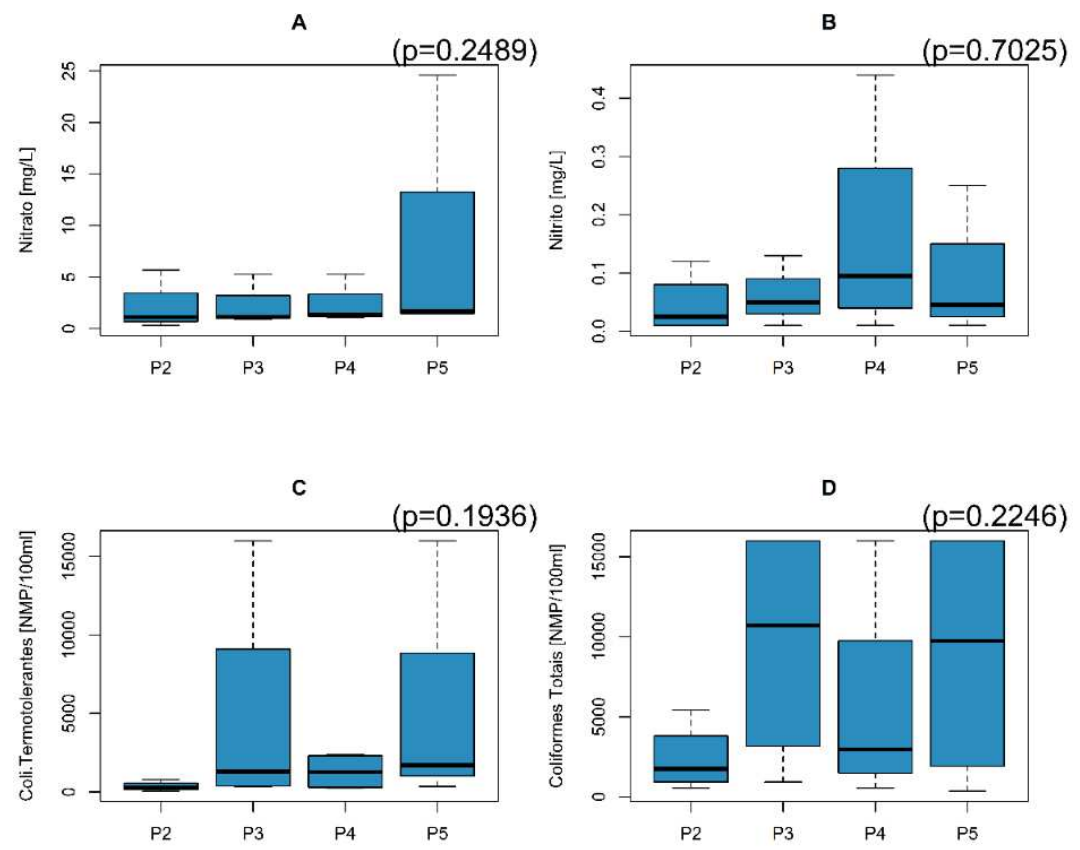

Fonte: organizado pelos autores, 2020.

Considerando o resultado dos valores de "p" na aplicação do teste de Kuskall Wallis para as frequências espaço-sazonais, revela-se que não existe diferença significativa entre os indicadores químicos; nitrato $\mathrm{p}=0,2489$ (figura 8a) e nitrito $\mathrm{p}=0,7025$ (figura 8b); e biológicos; 
coliformes termotolerante $\mathrm{p}=0,1936$ (figura 8c) e coliformes totais $\mathrm{p}=0,2246$ (figura 8d) nos diferentes pontos amostrais, pois apresentam valores superiores a 0,05 (p>0,05). Dados este que, infelizmente apontam para a contaminação química e biológica em toda a extensão do rio Itajaí-Açu, independentemente da estação sazonal. Em pesquisa em rio no estado do Amapá, Abreu e Cunha (2017), relatam resultados químicos para nitrogênio e biológicos para o grupo coliformes que corroboram com o estudo do rio em questão para a qualidade da água, apontando para fortes impactos antrópicos na bacia, tais como os urbanos e industriais. Salienta-se que os componentes obtidos através do uso da técnica estatística são de fiabilidade para indicadores da qualidade de água, elucubrando sobre o efeito das atividades antrópicas na qualidade das águas de uma bacia.

Os resultados obtidos no teste de Spearman, para correlações entre o uso e ocupação do solo às margens do rio Itajaí-Açu e os indicadores químicos e biológicos, conforme plano amostral por trechos, nas diferentes estações, está apresentado na figura 9.

Figura 9. Correlação entre as variáveis a partir do coeficiente de Spearman
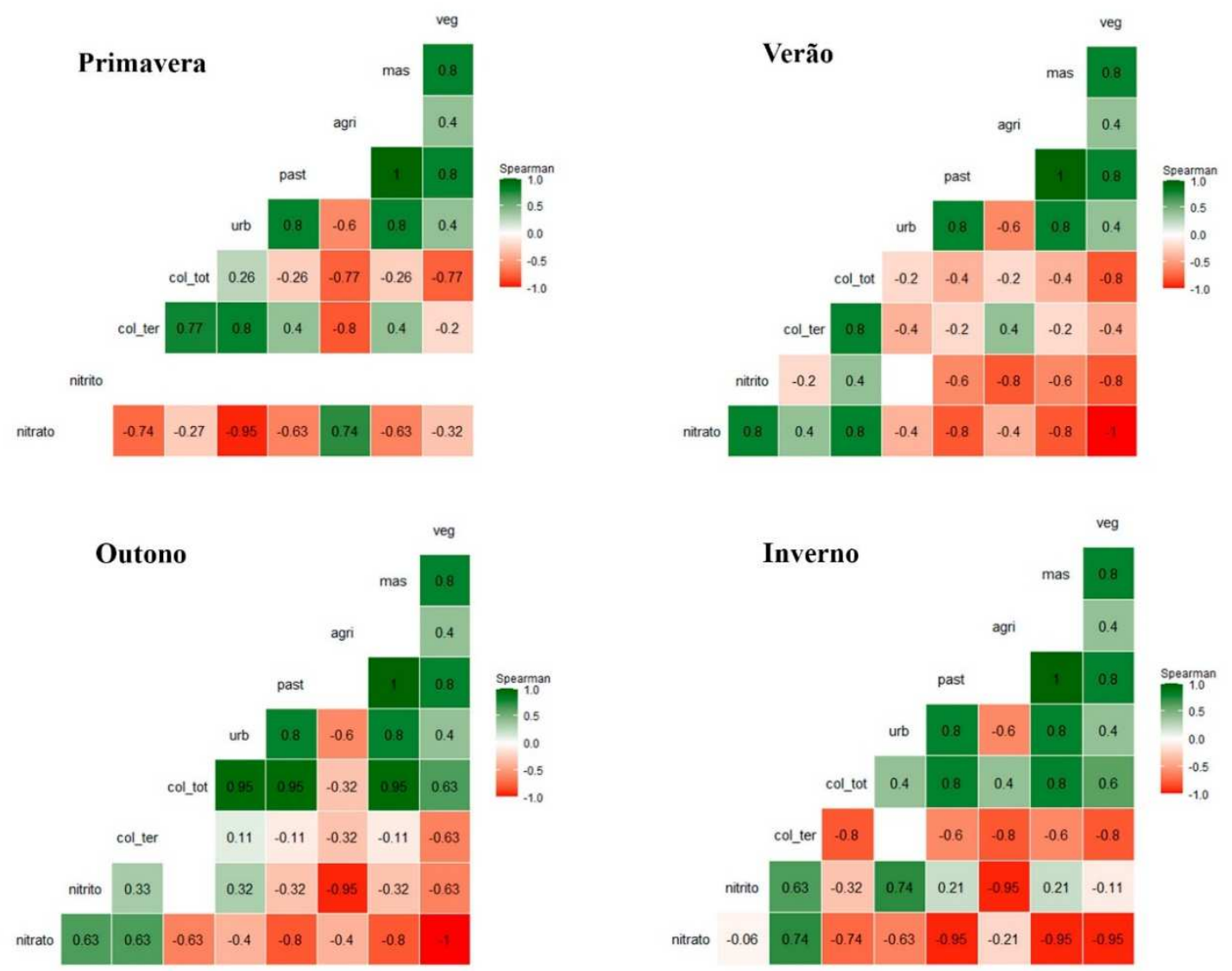

Fonte: organizado pelos autores, 2020. 
A correlação igual ou superior a 0,7 é considerada uma correlação forte, sendo mais forte quando de aproximar do valor 1,0. Os valores positivos indicam que as duas variáveis se movem juntas e negativos quando as duas variáveis se movem em direções opostas para a hipótese (FREIRE; CASTRO, 2014).

Considerando a análise acima e os resultados obtidos na figura 9, apenas para correlação forte (mínimo 0,7), o indicativo nitrato apresentou uma correlação negativa em relação a classe pastagem nas estações verão, outono e inverno ( $\mathrm{r}=-0,8 ;-0,8 ;-0,95$, respectivamente) e com a classe vegetação no outono e inverno ( $\mathrm{r}=-1$ e $-0,95$ respectivamente). Esses resultados apontam na redução da lixiviação do indicativo nos cursos hídricos devido ao período de desenvolvimento das gramíneas forrageiras nas pastagens (fevereiro, abril e julho), haja vista que o vegetal absorve o nitrato do solo para o seu crescimento durante seu ciclo produtivo (Embrapa; Cidasc, 2020). Fernandes et al., (2017) em estudo de impacto da fertilização nitrogenada em pastagens aponta também, para a redução do indicativo no solo durante o ciclo de desenvolvimento das gramíneas, pois estas absorvem quantidades diferenciadas de nitrogênio sob a forma de nitrato $\left(\mathrm{NO}^{3-}\right)$ e amônio $\left(\mathrm{NH}^{4+}\right)$. Já, na correlação com a vegetação, o resultado pode estar associado a baixa pluviosidade nas estações outono (precipitação acumulada $=0,0 \mathrm{~mm}$ ) e inverno (precipitação acumulada $=0,8 \mathrm{~mm}$ ), onde a remanescente vegetação ao longo do rio Itajaí-Açu, consegue atenuar parte da carga do poluente. Bacellar (2005) em estudo de florestas no regime hidrológico de bacias hidrográficas, apresenta a mata ciliar um redutor que favorece a desnitrificação das águas dos fluxos subterrâneos e subsuperficiais e, isto posto, têm-se empregado matas ciliares para controle da contaminação por nitrato em zonas rurais.

A correlação positiva do nitrato com a classe agricultura na primavera $(r=0,74)$ e com o indicativo coliformes totais no verão $(r=0,8)$, corrobora com as literaturas supracitadas, pois o aumento do indicativo no curso hídrico pode ser justificado pela soma do preparo do solo adubação nitrogenada química e por esterco (fezes de animais) - para o plantio de pastagens e arrozeiras na primavera (setembro à novembro), cultivares típicos ao longo do rio Itajaí-Açu e a alta pluviosidade nas estações primavera e verão (precipitação acumulada: 21,4 mm;20mm, respectivamente), que lixivia o indicativo para a rio. Entretanto, no inverno, com a ausência de chuva no período (precipitação acumulada $=0,0$ ) o nitrato foi reduzido com o aumento dos coliformes totais $(\mathrm{r}=-0,74)$. Processo este lídimo, por ação de bactérias do gênero 
Pseudomonas, denominado desnitrificação, onde o indicativo é reduzido a nitrogênio (N2) de forma anaeróbia, na presença de matéria orgânica (esgotamento sanitário). Zoppas, Bernardes e Meneguzzi (2016) afirmam que a desnitrificação ocorre em ambientes pouco aerados, onde retorna-se o nitrogênio para o ambiente, a partir do nitrato, pela ação anaeróbia de bactérias Pseudomonas na presença de uma fonte de carbono.

O indicativo nitrito apresentou uma correlação negativa com a classe agricultura no verão $(r=-0,8)$, outono $(r=-0,95)$ e inverno $(r=-0,95)$ e também, com a classe vegetação $(r=-$ $0,8)$ no verão. Resultados fomentam a diminuição da presença do indicativo no rio, ao processo de nitrificação após adubação em fase de panícula do cultivo de arroz nos meses de setembro a outubro. A nitrificação é o termo usado para descrever a primeira etapa do processo de remoção biológica de nitrogênio, em que a amônia (fertilizante químico) é oxidada a nitrito e o nitrito é oxidado a nitrato (ZOPPAS; BERNARDES; MENEGUZZI, 2016). As plantas ao atingirem um grau de desenvolvimento, reduzem o nitrato através das raízes e folhas e o transportam para diferentes órgãos sob a forma de aminoácidos. Resultado este, apontado em estudo de Lanna e Carvalho (2013), na redutase do nitrato em cultivares de arroz. Na primavera, o indicativo nitrito não foi possível calcular a correlação, pois apresentou constância de valores nos cinco pontos amostrais.

Considerando o grupo coliformes (totais e termotolerantes), escrutina-se que os indicativos são minimizados com a presença da vegetação em todas estações sazonais e influenciados negativamente pela ação da antropização (urbanização; pastagens) nos mesmos períodos. Conforme Dos Santos Souza et al. (2018), altos índices de coliformes totais indicam contaminação pós-sanitização ou pós-processo, tratamentos térmicos ineficientes ou multiplicação durante o processo. Já altos índices de coliformes termotolerantes indicam contaminação fecal e aferem as condições higiênico-sanitárias do corpo d'água.

Anuindo com a análise anterior, o indicador coliforme total obteve uma correlação negativa com a classe vegetação na primavera e no verão ( $r=-0,77$ e $-0,8$, respectivamente), e positiva com a classe urbanização no outono $(\mathrm{r}=0,95)$. Os resultados para as duas primeiras estações apontam para a diluição do indicativo com o alto regime de chuvas no período, bem como a atuação filtro da mata ciliar às margens no rio Itajaí-Açu. Entretanto, no outono, o excesso de carga orgânica advindo de efluentes industriais, sendo estes resultados da falta de fiscalização da eliminação dos dejetos industriais nos município que integram a bacia do Itajaí, 
bem como a inexistência de pluviosidade no período (precipitação acumulada=0,0), culminou na elevação do indicativo, haja vista que os coliformes termotolerantes, advindos de fezes humanas (efluentes domésticos), não foram representativos para esta estação.

Coliformes termotolerantes e totais apresentaram uma correlação positiva na primavera $(\mathrm{r}=0,77)$; verão $(\mathrm{r}=0,8)$, sendo estes, decorrentes do despejo de efluentes domésticos e industriais, ou seja, a contaminação tanto por fezes humanas como por outros mamíferos ao longo do rio devido ao baixo índice de esgotamento sanitário na região. Sua inversão, correlação negativa no inverno, pode ser fundamentada pela diminuição da atividade metabólica bacteriana em detrimento a diminuição da temperatura na estação. Conforme Wagner et al. (2018), esses microrganismos são considerados mesófilos em relação à temperatura de crescimento, ou seja, a faixa ótima de crescimento é entre 25 a $40{ }^{\circ} \mathrm{C}$. e, em temperaturas abaixo de $25^{\circ} \mathrm{C}$ a reprodução destas bactérias decresce.

O indicador coliforme termotolerantes manifestou correlação negativa com a classe agricultura, na primavera e no inverno ( $r=-0,8$ para ambas estações), e também para a classe vegetação no inverno $(\mathrm{r}=-0,8)$. Entretanto, denotou correlação positiva com a classe urbanização somente na primavera $(\mathrm{r}=0,8)$. Dados são corroborados com os autores, já abordados como Freire (2020); Dos Santos Souza et al. (2018); Nunes et al. (2019) e Vieira (2019) que versam sobre a importância da vegetação às margens dos cursos hídricos na manutenção salutar da potabilidade hídrica, assim como a influência negativa da antropização sobre o curso hídrico em decorrência das variações de precipitação e temperatura nos diferentes períodos sazonais.

\section{CONCLUSÃO}

Os resultados obtidos através do uso da análise estatística são de fiabilidade para o monitoramento dos indicadores da qualidade de água, elucubrando sobre o efeito das atividades antrópicas na qualidade das águas de uma bacia hidrográfica.

Diante dos dados obtidos neste estudo, entende-se que as águas do rio Itajaí-Açu se encontram potencialmente contaminadas por coliformes totais e coliformes termotolerantes, demonstrando influência antrópica do uso inadequado do solo no tocante ao despejo de efluentes, urbano e industriais, sem tratamento no curso hídrico. 
Os valores obtidos para o indicativo coliformes termotolerantes na confluência do rio, no município de Rio do Sul desqualifica suas águas como própria para consumo e também para a balneabilidade, ratificando a contaminação fecal humana. Seu resultado transcende a quantidade mínima estabelecida na Resolução n³57/2005 do CONAMA de 1000 NMP por 100 ml de água, sendo assim enquadrado em água de classe 4, destinada apenas à navegação e a harmonia paisagística. Isto posto, aponta-se para a contaminação biológica à montante da confluência do rio Itajaí-Açu e posterior contaminação ao longo do seu curso.

Resultados evidenciados no ponto 2, município de Apiúna, revelam a remanescente vegetação às margens do rio como atenuante da carga de poluentes lançada no curso hídrico, tanto para os indicativos químicos advindos da adubação das áreas agricultáveis da região, como para os indicativos biológicos resultantes de efluentes urbanos e industriais. Esta região em questão, se enquadrada como água de classe 2, segundo a Resolução n³57/2005 do CONAMA, destinada a consumo humano após tratamento convencional, recreação de contato primário e irrigação de hortaliças.

A falta de saneamento básico e a ausência ou precariedade de um plano de gestão para o uso adequado da ocupação do solo dos municípios às margens do rio Itajaí-Açu fícou evidenciado na presente pesquisa. É imprescindível ação do poder público para o desenvolvimento de políticas e diretrizes voltadas ao planejamento territorial com vistas a qualidade das águas nas bacias hidrográficas e sua ocupação. Além de infringir o princípio legal da dignidade humana de acesso à água limpa e ao esgotamento sanitário adequado, o descaso contribui para o aumento da degradação ambiental do território bem como a salubridade da sua população.

Desafiar a retórica das leis e os contornos da gestão pública é um esforço a ser continuado no sentido de realizar ações concretas, exercitando a crítica em face aos conflitos de gerenciamento ambiental, entre vida social e meio-ambiente, entre território e cidade, intervindo assim, integralmente em defesa ao meio ambiente e na dignidade do cidadão brasileiro.

\section{REFERÊNCIAS}

ABREU, C. H. de M; CUNHA, A. C. Qualidade da água e índice trófico em rio de ecossistema tropical sob impacto ambiental. Eng. Sanit. Ambient., Rio de Janeiro, v. 22, n. 1, p. 45-56, fev. 2017. 
ALMEIDA, R. F. B; BAYER, M.; J, FERREIRA, L. G. Compartimentação morfométrica da bacia do rio Coco como subsídio a análise de fragilidade ambiental. Mercator (Fortaleza), Fortaleza, v. 15, n.4, p.83-94, dez. 2016.

ANDRIETTI, G. et al. Índices de qualidade da água e de estado trófico do rio Caiabi, MT. Revista Ambiente \& Água, v. 11, n. 1, p. 162-175, 2016.

ASCIUTTI, G. A. M.; STANGANINI, F. N.; MELANDA, E. A. Identificação dos diferentes usos e ocupação do solo da bacia hidrográfica do rio do quilombo, São Carlos/SP utilizando imagem do satélite sentinel 2 e o complemento scp do qgis. In: ANAIS DO XIX SIMPÓSIO BRASILEIRO DE SENSORIAMENTO REMOTO, 2019, Santos. Anais eletrônicos. São José dos Campos, INPE, 2019.

BACELLAR, L. de A. P. O papel das florestas no regime hidrológico de bacias hidrográficas. Geo. br, v. 1, p. 1-39, 2005.

BRASIL. Lei n. 9.433, de 8 de janeiro de 1997. Institui a Política Nacional de Recursos Hídricos, cria o Sistema Nacional de Gerenciamento de Recursos Hídricos. Diário Oficial da República Federativa do Brasil, Poder Executivo, Brasília, DF, 09 jan. 1997. Disponível em: http://www.planalto.gov.br/ccivil_03/leis/19433.htm. Acesso em: 09 de set. de 2020.

BRASIL. Conselho Nacional do Meio Ambiente - CONAMA. Resolução no 357 de 17 de março de 2005. Brasília, 2005. Dispõe sobre a classificação dos corpos de água e diretrizes ambientais para o seu enquadramento, bem como estabelece as condições e padrões de lançamento de efluentes, e dá outras providências. Diário Oficial da União, Brasília, DF, 18 mar. 2005, págs. 58-63 Disponível em:

http://www2.mma.gov.br/port/conama/legiabre.cfm?codlegi=459. Acesso em 20 abr. 2020.

BASTOS, R. K. X.; BEZERRA, N. R.; BEVILACQUA, P. D. Planos de segurança da água: novos paradigmas em controle de qualidade da água para consumo humano em nítida consonância com a legislação brasileira. In: $\mathbf{2 4}^{\mathbf{0}}$ Congresso Brasileiro de Engenharia Sanitária e Ambiental. 2007.

CIDASC. COMPANHIA INTEGRADA DE DESENVOLVIMENTO AGRÍCOLA DE SANTA CATARINA. Pesquisa desenvolve capim azevém que produz $5 \%$ mais e 20 dias mais cedo. Disponível em: http://www.cidasc.sc.gov.br/blog/2017/09/02/pesquisadesenvolve-capim-azevem-que-produz-5-mais-e-20-dias-mais-cedo/. Acesso em: 20 set. 2020.

CORNELLI, R. et al. Análise da influência do uso e ocupação do solo na qualidade da água de duas sub-bacias hidrográficas do município de Caxias do Sul. Scientia cum Industria, [S. 1.], v. 4, n. 1, 2016.

DE MELO, M. T. et al. Qualidade da água para a irrigação, a sustentabilidade de uma bacia hidrográfica-riacho queima pé, Tangará da Serra/MT. Caminhos de Geografia, v. 21, n. 76, p. 16-27-16-27, 2020.

DE MENDONÇA, D. S.; MAGALHÃES, S. C. M.; TRINDADE, W. M. Água e saúde: uma análise do córrego entre rios em Pirapora-MG. Hygeia, v. 11, n. 20, p. 189-200, 2015.

DOS SANTOS SOUZA, Q. et al. Análise de coliformes totais e termotolerantes-fecais em diferentes pontos da sub-bacia do rio Poxim-Sergipe, Brasil. Agroforestalis News, v. 3, n. 1, p. 1-21, 2018. 
EMBRAPA. EMPRESA BRASILEIRA DE PESQUISA AGROPECUÁRIA. Forrageiras espécies para a Região Sul do Brasil. Disponível em: https://www.embrapa.br/climatemperado/forrageiras. Acesso em: 18 set. 2020.

FERNANDES, G. et al. Impacto da fertilização nitrogenada em pastagens perenes na contaminação dos recursos naturais. Revista Brasileira de Tecnologia Agropecuária, v. 1, n. 1, p. 03-14, 2017.

FONSECA, A. L. Determinação do índice de nitrato, nitrito e nitrogênio amoniacal na água da lagoa de Extremoz/RN. 2017. 48p. Trabalho de Conclusão de Curso (Bacharel em Química do Petróleo) - Universidade Federal do Rio Grande do Norte, Natal, 2017.

FREIRE, A. P., CASTRO, E. de C. Análise da correlação do uso e ocupação do solo e da qualidade da Água. Revista Brasileira de Recursos Hídricos, 19, 41-49, 2014.

FREIRE, L. L. Variação sazonal e interanual da qualidade das águas de rios do semiárido brasileiro. 2020. 160p. Dissertação (Mestrado em Engenharia Civil) Universidade Federal do Ceará, Fortaleza, 2020.

FURLAN, A. R.; FILIPINI, R. C.; REIS, J. T. Os diferentes tipos de uso e cobertura da terra e sua influência nos parâmetros de qualidade da água. Ciência e Natura, v. 38, n. 3, p. 13191330, 2016.

GREENBERG, A. E.; CLESCERI, L. S.; EATON, A. D. Method 9221- Multiple-tube fermentation technique for members of the coliform group. Standard methods for the examination of water and wastewater, p. 9-45, 1992.

IBGE. INSTITUTO BRASILEIRO DE GEOGRAFIA E ESTATÍSTICA. Cidades, 2010. Disponível em: https://cidades.ibge.gov.br. Acesso em: 20 set. 2020.

KARASIAK, N. Dzetsaka plugin. Método de classificação Gaussian Mixture Model. Disponível em: https://plugins.qgis.org/plugins/. Acesso em julho 2019.

LANNA, A. C.; CARVALHO, M. A de F. Nitrato redutase e sua importância no estabelecimento de plantas de arroz de terras altas. Embrapa Arroz e Feijão, Santo Antônio de Goiás, v. 37, 2013.

LIMA, J. A. M.; BETHONICO, M. B. M.; VITAL, M. J. S. Água e doenças relacionadas à água em comunidades da bacia hidrográfica do rio Uraricoera-terra indígena YanomamiRoraima. Hygeia, v. 14, n. 27, p. 136-154, 2018.

MARTINS, A. L. M; LOPES, M. C.; SIMEDO, M. B. L. Monitoramento de qualidade de água: suporte para gestão ambiental na microbacia do córrego da Olaria. ANAP, Brasil, v. 11, n. $6,2015$.

MIOT, H. A. Avaliação da normalidade dos dados em estudos clínicos e experimentais. Jornal vascular brasileiro, v. 16, n. 2, p. 88-91, 2017.

NUNES, L. M. et al. Pesquisa de coliformes totais e termotolerantes no rio Salgadinho no município de Juazeiro do Norte, CE. Revista Eletrônica Acervo Científico, v. 7, p. e2243e2243, 2019.

OKUMURA, A. T. R. et al. Determinação da qualidade da água de um rio tropical sob a perspectiva do uso. Revista Brasileira de Geografia Física, v. 13, n. 04, p. 1835-1850, 2020. 
PEREIRA, R. H. de A. Análise espaço temporal de parâmetros de qualidade de água e sua relação com uso e ocupação na bacia do Alto Tietê. 2016. 105p. Trabalho de Conclusão de Curso (Engenharia Ambiental) - Universidade Estadual Paulista, Rio Claro - SP, 2016. Disponível em: https://repositorio.unesp.br/handle/11449/144007. Acesso em: 12 nov. 2020.

PLANO DE RECURSOS HÍDRICOS DA BACIA DO ITAJAÍ. Caderno Síntese: para que a água continue a trazer benefícios para todos. Fundação Agência de Água do Vale do Itajaí. v. 1, Blumenau, SC, 2010.

QGIS. Development Team. QGIS Geographic Information System. Open Source Geospatial Foundation Project, Versão 2.18. "Las Palmas". Disponível em: https://www.osgeo.org/projects/qgis/. Acesso em: 15 jun. 2019.

R. Core Team. R: A language and environment for statistical computing. $R$ Foundation for Statistical Computing, Vienna, Austria, 2020. Disponível em: https://www.R-project.org/.

SANTOS, L. A. C. et al. Conflitos de Uso e Cobertura do Solo para o Período de 1985 a 2017 na Bacia Hidrográfica do Rio Caldas-GO. Fronteiras: Journal of Social, Technological and Environmental Science, v. 8, n. 2, p. 189-211, 2019.

SILVA, J. M. O. Uso do sensoriamento remoto para a estimativa da temperatura de superfície na microbacia do rio Granjeiro/Crato-Ceará. Geosaberes, v. 6, n. 2, p. 130-144, 2015.

SNIS. Sistema Nacional de Informações sobre Saneamento, 2018. Águas e Esgotos. Disponível em: http://appsnis.mdr.gov.br/indicadores/web/agua_esgoto/mapa-esgoto. Acesso em: 18 set. 2020.

VIEIRA, I. C. B. Mapeamento da área de preservação permanente na margem norte do rio Itajaí-Açu em área urbana consolidada. Metapre, v. 1, p. 26-29, 2019.

WAGNER, L. G. et al. Monitoramento de coliformes termotolerantes em lodo de esgoto higienizado por via térmica, 2018.

YKEIZUMI, L. Y. F.; VIEIRA, I. C. B.; KROTH, G. A. B. Estudos do crescimento urbano no município de Ilhota-SC no período de 1999-2019. Metapre, v. 2, p. 10-14, 2020.

ZOPPAS, F. M; BERNARDES, A. M.; MENEGUZZI, A. Parâmetros operacionais na remoção biológica de nitrogênio de águas por nitrificação e desnitrificação simultânea. Engenharia Sanitária e Ambiental, v. 21, n. 1, p. 29-42, 2016. 